\title{
Workplace Loneliness and OCB: The Mediation Role of Affective Commitment
}

\author{
Ghista Dilla ${ }^{a,{ }^{*}}$ Yulihardi ${ }^{b, *}$ \\ ${ }^{a}$ Magister of Management, Graduate Program, Universitas Lancang Kuning, Indonesia. \\ ${ }^{\mathrm{b}}$ Universitas Baiturrahmah, Sumatera Barat, Indonesia.
}

\begin{tabular}{llll}
\hline ABSTRACT & & ARTICLE HISTORY \\
\hline This study aims to determine whether loneliness at work and OCB affect the & & Accepted: December 31, 2021 \\
Mediation Role of Affective Commitment. The location of this research was & & \\
conducted at PT. Green Planet Indonesia branch Pekanbaru, Riau. While the & & KEYwORDS \\
time of the study was carried out from April to June 2021. The source of this & & Workplace Loneliness and OCB: \\
research data is the respondent PT. Green Planet Indonesia. With 50 & & Mediation Role of Affecitive \\
respondents as the research sample. The data analysis used in this paper is & & Commitment. \\
PLS Structural Equation Modeling (SEM) which is operated through the & \\
SmartPLS program. The results of this paper indicate that Workplace & \\
Loneliness has a negative and significant effect on Organizational & \\
Citizenship Behavior on employees at a private company PT. Green Planet & \\
Indonesia. Workplace Loneliness has a negative and significant effect on & \\
Affective Commitment to employees at a private company PT. Green Planet & \\
Indonesia. Affective commitment has a positive and significant effect on & \\
Organizational Citizenship Behavior on employees at a private company PT. & \\
Green Planet Indonesia. Affective commitment is not able to mediate & \\
workplace loneliness on Organizational Citizenship Behavior on employees & \\
at a private company PT. Green Planet Indonesia. & \\
\hline
\end{tabular}

\section{Introduction}

Research that discusses wp becomes interesting during the covid-19 pandemic that hit the whole world. Why? Because wp makes people aware of their health, environment and friendship. In addition to the pressure that comes from the work environment, the family environment and social environment also have the potential to cause anxiety. Considering that the positive cases of Covid-19 in the world, especially in Indonesia, continue to soar so that it still poses a big risk of transmission in the community. That way, the state enforces a WFH (Work From Home) system for every worker, including government employees. The following system triggers the emergence of stress while working at home and has an impact on the weaker mind on most workers or employees. Job stress is a dynamic condition in which each individual faces an opportunity, constraint, or demand related to what is needed, the result of which is perceived as uncertainty. Decenzo and Robbins (2010:328) state, stress is a dynamic condition in which each individual faces an opportunity, constraint, or request related to what is needed, the result of which is perceived as uncertainty. Stress can be defined as a response brought about by various external events and can be in the form of positive

* CORRESPONDING AUTHOR. Email: ghistadilla29@gmail.com. 
experiences or negative experiences (Jagaratnam and Buchanan, 2004). Luthan (2008:247) states that stress is not just nervous tension, stress can have positive consequences, stress is not something to be avoided, and the absence of stress at all is death.

Workplace Loneliness found support that greater workplace loneliness is associated with lower job performance; mediators of this relationship are employees who are more lonely to approach and lower affective commitment to their organization. Loneliness---"a complex set of feelings that arises when intimate and social needs are not adequately met" (Cacioppo et al., 2006: 1055) - is an unpleasant psychological state. Surprisingly, there has been little examination of the processes and outcomes of workplace loneliness, even though most people spend most of their lives at work.

Loneliness, similar to other types of affect, has been characterized as a state and a sentiment, but is not generally considered a trait (although it can be chronic) (Peplau \& Perlman, 1982; Spitzberg \& Hurt, 1989). Since loneliness is a subjective experience, an employee does not have to be alone to feel lonely, and a lonely employee can feel lonely even when interacting frequently with many other people if these interactions do not provide the lonely employee with the desired level of closeness (Fischer \& Phillips, 1982). . Whether employees feel lonely depends on the level of closeness, security, and support they seek in their interpersonal relationships (Jones \& Hebb, 2003). Thus, the same work environment can meet the interpersonal needs of some employees while other employees feel lonely.

\section{Theoretical support}

\section{Social Exchange Theory (SET)}

Social Exchange Theory (SET) is one of the most influential conceptual paradigms in understanding the work behavior of employees in an organization. Empirical studies of social exchange theory can be traced to the period of the 1920s Malinowski (1922); Mauss (1925). One of the figures who developed the theory of social exchange, among others, is psychology (Blau, 1964). Furthermore, it is said that social exchange is a feeling that causes a common perception of future goals. In view of this theory, employees will be motivated and committed to work and the organization if they are treated fairly and equally. Furthermore, Bass (1990) stated that SET theory is aimed at understanding the relationship between leaders and their subordinates and understanding the factors related to documents (Mowdey et.al., 1982).

\section{Workplace Loneliness}

Workplace Loneliness is the subjective affective evaluation of employees, and feelings about, whether their affiliation needs are being met by the people they work with and the organizations they work for (Ozcelik \& Barsade, 2018). 


\section{Affective Commitment}

Hartmann and Bambacas (2000) define that affective commitment refers to a feeling of belonging, feeling attached to the organization and having a relationship with personal characteristics, organizational structure, work experience such as salary, supervision, role clarity, and various skills. Buchanan (in Allen and Meyer, 1990) describes affective commitment as an individual's participation in organizational goals and values based on the psychological bond between the individual and the organization. Mowday et al (in Allen and Meyer, 1990) have their own definition of affective commitment, which is a strong relationship between individuals and organizations or companies identified by their participation in company or organizational activities. Furthermore, Becker (in Allen and Meyer, 1990) describes affective commitment as a tendency to engage in organizational activities consistently as a result of the accumulated investment that is lost if the activity is stopped.

\section{Organizational Citizenship Behavior (OCB)}

Organizational Citizenship Behavior (OCB) is part of the science of organizational behavior, OCB is a form of work behavior that is usually not seen or taken into account. There are two approaches to the OCB concept, namely OCB is an extra role performance that is separate from in-role performance or performance according to the job description. The second approach is to view OCB from a political principle or philosophy. This approach identifies the behavior of organizational members with citizenship behavior. The existence of OCB is the impact of individual beliefs and perceptions in the organization on the fulfillment of psychological agreements and contracts. This behavior arises because the individual feels as a member of the organization who has a sense of satisfaction when he can do something more than the organization (Saleem and Amin, 2013).

\section{Research method}

\section{Explanatory Study Research}

This research is an explanatory study, namely research that aims to explain why an event occurs and to build, expand, elaborate or test theory (Neuman, 2011). This study aims to explain the mechanism that underlies the relationship between interpersonal conflict and the behavior of hiding knowledge based on theory. In other words, this research is an explanatory research that uses quantitative methods to test hypotheses empirically. In social research, especially in the field of management, quantitative method is a research method rooted in the positivist social science approach which "emphasizes discovering causal law, careful empirical observations and value-free research" (Neuman, 2014, p. 97). This study then utilizes a crosssectional survey in collecting research data to test the formulated hypotheses. 


\section{Results}

\section{SEM-PLS Analysis}

Data analysis in this study tested the effect of several independent variables on the dependent variable and the moderating variable. Hypothesis testing was carried out using the Partial Least Square (PLS) method. Partial Least Square is a structural Equation Modeling (SEM) solution method. Research with the title of Lonely's influence on Organizational Citizenship Behavior with Commit as moderating on employees of one company PT. Green Planet Indonesia. In analyzing the research data using SEM analysis with the WarpPLS 5.0 application. The steps in analyzing the data are as follows:

\section{a. Outer Model}

b. Data management in this study uses PLS (partial least square) where the dependent variable is OCB $(\mathrm{Y})$, while the independent variable is lonely $(\mathrm{X})$, and the mediating variable is Commit $(Z)$. The fit model is used with the aim of testing the overall level of suitability of the research model. Testing the significance of the independent variable on the test dependent variable can be declared significant by fulfilling the requirements if the $P$ value is less than 0.05 .

Table 1. Analysis of Outer Model Fit.

\begin{tabular}{lll}
\hline Model & Fit Indices & P Values \\
\hline APC & 0.468 & $\mathrm{P}<0.001$ \\
ARS & 0.443 & $\mathrm{P}<0.001$ \\
AVIF & 1.190 & Good if $<5$ \\
\hline \multicolumn{2}{c}{ Notes. Processed Data 2021 } &
\end{tabular}

The output in table 1 shows that the fit model indicator with APC 0.468 , ARS 0.443 and P value $<0.001$ is significant because it meets a significant value of 0.05 . While the AVIF of 1,190 met the requirements of less than 5 , the research data was tested with a fit model and the research data was declared fit so that the research data did not occur multicollinearity.

c. Combined Loading and Cross Loading

Variables with low loading values indicate that the indicator does not have a good effect on reflective indicators $>0.7$ while the formative variables of each variable provide the largest contribution to the construct. At 5\% alpha and t-statistic $>1.96$. Cross loading is another measure of discriminant validity.

Table 2. Combined Loading and Cross Loading.

\begin{tabular}{cccccc}
\hline & Lonely & Commit & OCB & SE & P Value \\
\hline WP3 & 0.759 & -0.130 & 0.553 & 0.106 & $<0.001$ \\
WP7 & 0.522 & -0.220 & -0.189 & 0.116 & $<0.001$ \\
WP9 & 0.853 & -0.113 & -0.145 & 0.102 & $<0.001$ \\
WP13 & 0.524 & 0.307 & -0.440 & 0.116 & $<0.001$ \\
WP14 & 0.565 & -0.132 & 0.071 & 0.114 & $<0.001$ \\
WP15 & 0.587 & -0.094 & 0.265 & 0.113 & $<0.001$ \\
\hline
\end{tabular}




\begin{tabular}{cccccc}
\hline WP16 & 0.667 & 0.219 & -0.337 & 0.109 & $<0.001$ \\
WP19 & 0.804 & 0.060 & 0.162 & 0.104 & $<0.001$ \\
WP20 & 0.880 & 0.096 & -0.076 & 0.101 & $<0.001$ \\
KA1 & 0.021 & 0.487 & 0.228 & 0.117 & $<0.001$ \\
KA2 & 0.463 & 0.684 & 0.359 & 0.109 & $<0.001$ \\
KA3 & 0.059 & 0.859 & -0.001 & 0.102 & $<0.001$ \\
KA4 & -0.319 & 0.761 & -0.338 & 0.106 & $<0.001$ \\
KA5 & -0.170 & 0.794 & -0.124 & 0.104 & $<0.001$ \\
OC1 & -0.293 & 0.218 & 0.739 & 0.106 & $<0.001$ \\
OC2 & -0.363 & 0.388 & 0.651 & 0.110 & $<0.001$ \\
OC3 & -0.445 & 0.293 & 0.714 & 0.107 & $<0.001$ \\
OC4 & 0.240 & -0.366 & 0.725 & 0.107 & $<0.001$ \\
OC5 & 0.382 & -0.237 & 0.751 & 0.106 & $<0.001$ \\
OC6 & 0.265 & 0.194 & 0.734 & 0.107 & $<0.001$ \\
OC7 & 0.166 & -0.465 & 0.692 & 0.108 & $<0.001$ \\
\hline Notes. Processed Data 2021 & & & &
\end{tabular}

The results of the combined loading and cross loading test are that the refective and formative indicators in this study have an SE value $>0.7$ and a p-value $<0.001$ on all research variables, and are declared significant because $<0.05$.

d. Average Variance External

Table 3. Analysis of Average Variance Extracted (AVE)

\begin{tabular}{ccc}
\hline Lonely & commit & OCB \\
\hline 0.487 & 0.531 & 0.513 \\
\hline Notes. Processed Data 2021
\end{tabular}

Based on table 3 which states that AVE can be used to measure the amount of variance in the construct compared to the variance generated in the measurement. The results of the AVE test in this study on the lonely variable of 0.487 ; commits of 0.531 ; and OCB of 0.513 . The AVE value for all variables has exceeded 0.05 , so it can be said that it has met the standard of the AVE value.

\section{e. Inner Model}

Inner model is an analysis conducted to test the research hypothesis and answer the problems posed. Hypothesis testing is carried out according to the research framework carried out to analyze and test directly and indirectly between exogenous and endogenous variables with a moderation model. The significance level of testing this hypothesis is done by looking at the value of the p-value. 


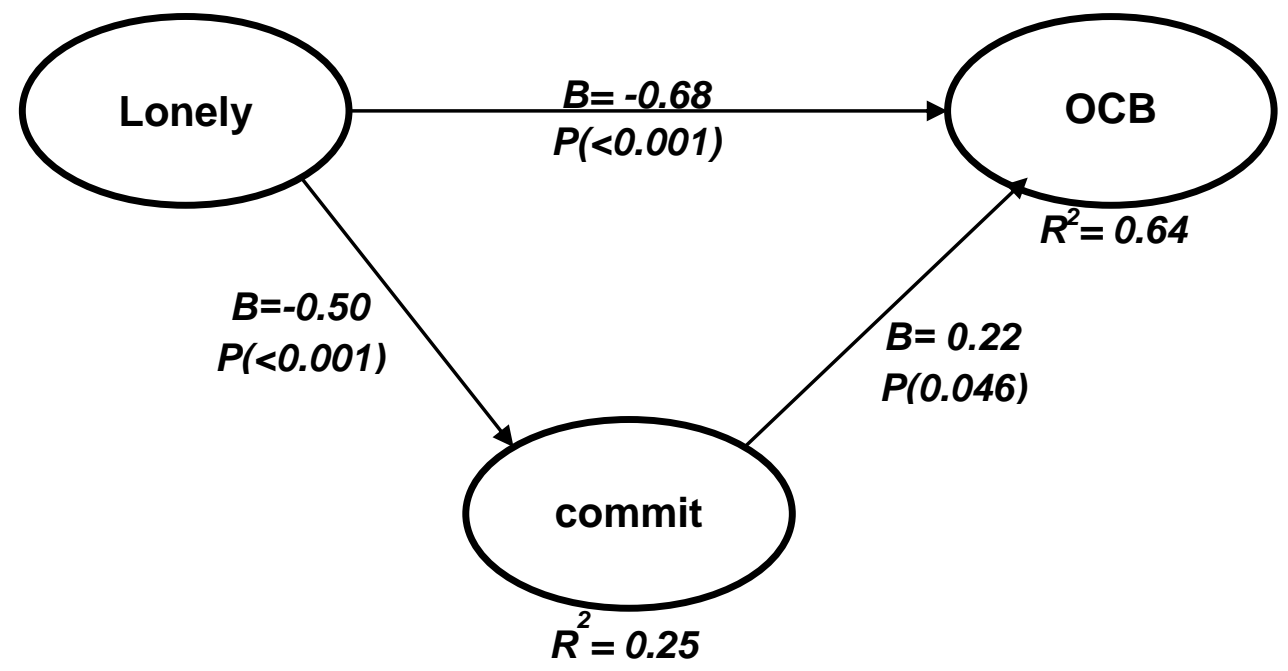

Figure 1. Structural Equation.

Figure 1 shows the results of the path coefficients with a significance level in accordance with the calculations that have been carried out using Warp PLS, so it can be concluded as in table 4 below:

Table 4. Analysis of Path coefficient and $p$ values

\begin{tabular}{|c|c|c|c|c|c|}
\hline \multicolumn{2}{|c|}{ Relationship between variables } & \multicolumn{2}{|c|}{ Path Coefficient } & \multicolumn{2}{|c|}{ Significance Level } \\
\hline Exogenous & Endogenous & Coeff. & P-value & value & Description \\
\hline Lonely (X) & $\mathrm{OCB}(\mathrm{Y})$ & -0.682 & $<0.001$ & $P<0.001$ & $\begin{array}{l}\text { High Negative } \\
\text { Significant }\end{array}$ \\
\hline Lonely (X) & Commit (Z) & -0.501 & $<0.001$ & $P<0.001$ & $\begin{array}{c}\text { Negative } \\
\text { Significant } \\
\text { High }\end{array}$ \\
\hline Commit (Z) & $\mathrm{OCB}(\mathrm{Y})$ & 0.223 & 0.046 & $P=0.04$ & Significant \\
\hline $\begin{array}{l}\text { Lonely }(\mathrm{X}) \rightarrow \\
\text { Commit }(\mathrm{Z})\end{array}$ & $\mathrm{OCB}(\mathrm{Y})$ & -0.111 & 0.125 & $\mathrm{P}=0.125$ & $\begin{array}{l}\text { Unable to } \\
\text { mediate }\end{array}$ \\
\hline
\end{tabular}

Based on Table 4 shows the calculation that the Lonely variable has a negative and significant effect on Organizational Citizenship Behavior (OCB). In this calculation, the path coefficient value is -0.682 with a significance level or $p$-value $<0.001$. The calculation explains that the lonely hypothesis has a negative effect on OCB (Hypothesis 1) is accepted and the relationship is negative. This means that lonely (X) has a significant effect on OCB (Y), the higher the lonely employee, the less OCB, and vice versa.

Lonely variable has a negative and significant effect on commits. In this calculation, the path coefficient value is -0.501 with a significance level or $p$-value $<0.001$. The calculation explains that the lonely hypothesis has a significant effect on affective commitment (Hypothesis 2) is accepted and the relationship is negative. This means that lonely $(\mathrm{X})$ directly has a significant 
effect on affective commitment $(Z)$, the higher the lonely employee, the lower the affective commitment (Z), this also applies to the opposite situation.

Calculation of the affective commitment variable has a positive and significant effect on Organizational Citizenship Behavior (OCB). In this calculation, the path coefficient value is 0.223 with a significance level or p-value of $0.04(<0.05)$. The calculation explains that the affective commitment hypothesis has an effect on OCB (Hypothesis 3 ) is accepted and the relationship is positive or unidirectional. This means that directly affective commitment $(Z)$ has a significant effect on OCB (Y), the higher the employee's affective commitment, the better the Organizational Citizenship Behavior (OCB), and vice versa.

The calculation on the commit variable as a mediating variable from lonely on Organizational Citizenship Behavior (OCB). In this calculation, the path coefficient value is -0.111 with a significance level of 0.125 or p-value $=0.125$. The calculation explains that the commit hypothesis as a mediating variable from lonely to OCB (Hypothesis 4) is rejected. This means that indirectly commit is not able to mediate the relationship from lonely to OCB.

\section{Discussions}

\section{Effect of Workplace Loneliness on Organizational Citizenship Behavior}

Calculation of the effect of the Workplace Loneliness variable has a negative effect on Organizational Citizenship Behavior. In this calculation, the path coefficient value is -0.682 with a significance level or p-value $<0.001$. The calculation explains that the Workplace Loneliness hypothesis has a negative effect on Organizational Citizenship Behavior and is accepted and the relationship is negative. This means that directly Workplace Loneliness (X) has a significant effect on Organizational Citizenship Behavior (Y), the higher the Workplace Loneliness of employees, the less Organizational Citizenship Behavior or vice versa. So this shows a negative consequence of the feeling of loneliness felt by employees and causes low OCB which can be seen from the lack of mutually encouraging behavior between coworkers in an organization.

\section{Effect of Workplace Loneliness on Affective Commitment}

Calculation of the influence of the Workplace Loneliness variable has a negative effect on Affective Commitment. In this calculation, the path coefficient value is -0.501 with a significance level or p-value $<0.001$. The calculation explains that the Workplace Loneliness hypothesis has a negative effect on accepted affective commitment and the relationship is negative. This means that directly Workplace Loneliness (X) has a significant effect on Affective Commitment (Y), the higher the employee's workplace loneliness, the lower the affective commitment or vice versa. According to Jung et al (2021) individuals who feel lonely at work focus more on negative information than positive information, and this causes a lack of social interaction or immersion with the organization so that attachment to the organization will decrease as well. 


\section{The Effect of Affective Commitment on Organizational Citizenship Behavior}

Calculation of the effect of the affective commitment variable has a positive effect on Organizational Citizenship Behavior. In this calculation, the path coefficient value is 0.223 with a significance level or p-value $<0.001$. The calculation explains that the Affective Commitment hypothesis has a positive effect on Organizational Citizenship Behavior and is accepted and the relationship is positive. This means that directly Affective Commitment (Z) has a significant effect on Organizational Citizenship Behavior (Y), the higher the employee's affective commitment, the higher the Organizational Citizenship Behavior or vice versa.

\section{Affective Commitment Mediates the relationship between workplace loneliness and OCB}

Calculation on the effect of affective commitment variable as a mediating variable from workplace loneliness to OCB. In this calculation, the path coefficient value is -0.111 with a significance level of 0.125 or $\mathrm{p}$-value $=0.125$. The calculation explains that the hypothesis of affective commitment as a variable that mediates workplace loneliness on OCM is rejected. This means that indirectly affective commitment as a mediating variable from workplace loneliness to $\mathrm{OCB}$, this shows the role of affective commitment does not affect the relationship between these two variables, where the size of the employee's affective commitment will not reduce feelings of loneliness at work so that it does not have an impact on high Organizational Citizenship Behavior.

\section{Conclusion}

From the results that have been described previously, it can be concluded that Workplace Loneliness has a negative and significant effect on Organizational Citizenship Behavior on employees at a private company PT. Green Planet Indonesia. Workplace Loneliness has a negative and significant effect on Affective Commitment to employees at a private company PT. Green Planet Indonesia Affective commitment has a positive and significant effect on Organizational Citizenship Behavior on employees at a private company PT. Green Planet Indonesia. Affective commitment is not able to mediate workplace loneliness on Organizational Citizenship Behavior on employees at a private company PT. Green Planet Indonesia.

\section{Acknowledgement}

We thank the anonymous reviewers for their valuable support and guidance in improving the quality of the paper. Furthermore, we thank Adi Rahmat and Muhammad Rasyid Abdillah for his feedback on earlier versions of the paper. Besides, we also thank Universitas Lancang Kuning, Indonesia, for their assistance and support along the undertaken of this research.

\section{Disclosure statement}

No potential conflict of interest was reported by the authors. 


\section{References}

Abdillah, M. R. C. T., (2020). Metode Penelitian: Perspektif Sains Organisasi. UNILAK PRESS.

Albert Mehrabian and Sheldon Ksionzky. A Theory of Affiliation. Pp. v, 212. Lexington, Mass.: Lexington Books, 1974.

Bell, 1985; Russell et al., 1980. Estimating length frequency distributions of large reef fish underwater

Bourque, L., \& Fielder, E. P. (2003). How to conduct self-administered and mail surveys (Vol. 3). Sage.

Cacioppo, Balogh, \& Cacioppo, 2015. Implicit attention to negative social, in contrast to nonsocial, words in the Stroop task differs between individuals high and low in loneliness: Evidence from event-related brain microstates.

Cacioppo, J. T., \& Hawkley, L. C. (2009). Loneliness. In M. R. Leary \& R. H. Hoyle (Eds.), Handbook of individual differences in social behavior (pp. 227-240). New York: Guilford.

Cacioppo, J. T., \& Hawkley, L. C. (2009). Perceived social isolation and cognition. Trends in Cognitive Sciences,13(10), 447-454. PMC ID number: 2752489. doi: 10.1016/j.tics.2009.06.005

Cacioppo, J. T., Hawkley, L. C., Ernst, J. M., Burleson, M., Berntson, G. G., Nouriani, B., Spiegel, D. (2006). Loneliness within a nomological net: An evolutionary perspective. Journal of Research in Personality, 40, 1054-1085.

Decenzo, David., dan Stephen, P. Robbins. 2010. Human Resource Management. Tenth Edition International Student Version.Tenth Edition.Asia : Wiley.

Depue RA, et al. Behav Brain Sci. 2005. A neurobehavioral model of affiliative bonding: implications for conceptualizing a human trait of affiliation.

Duton, J.E,, \& Heapy, E,D. (2003). The power of high-quality relationship at work. In K.S. Cameron, J.E Duton, \& R.E. Quinn (Eds), Positive organizational scholarship : Foundations of a new discipline (pp. 263278). San Francisco, CA : Berrett-Koehler Publishers.

Dutton, J.E. and Heaphy, E.D. (2003) The Power of High-Quality Connections.

Dyne, L. V., Ang, S., \& Botero, I. C. (2003). Conceptualizing employee silence and employee voice as multidimensional constructs. Journal of management studies, 40(6), 1359-1392.

Elfenbein,(2007).Emotion in organizations: A review and theoretical integration.Academy of Management Annals,1,371-457.

Fink, A. (2003). The survey handbook. sage.

Hakan, O. \& Sigal G. B. (2018). No Employe an Island: Workplace Loneliness and Job Performance. Academy of Management Journal Vol.61, No 6, 2343-2366.

Heinrich, L., \& Gullone, E. (2006). The Clinical Significance of Loneliness: A Literature Review. Clinical Psychology Review, 26, 695-718.

Hill, C. A. (1987). Affiliation motivation: people who need people ... but in different ways. Journal of Personality and Social Psychology, 52(5), 1008-1018

Jagaratnam, G., and P. Buchanan. 2004. Balancing The Demand of School and Work: Stress nd Employed Hospitality Student. International journal of Contemporary Hospitality Management. 16(4), pp:237245.

Luthans Fred, 2008. Organizational Behavior Eleventh Editions. Mc Graw Hill Irwin, Campanies, Inc. New York.

Malinowski, B (1961 [1922]) Argonauts of the Western Pacific: An Account of Native Enterprise and Adventure in the Archipelagos of Melanesian New Guinea. New York: E.P. Dutton \& Co.

Mayer, R. C., Davis, J. H., \& Schoorman, F. D. (1995). An integrative model of organizational trust. Academy of management review, 20(3), 709-734.

Meyer, J. P., Allen, N. J., \& Gellatly, I. R. (1990). Affective and continuance commitment to the organization: Evaluation of measures and analysis of concurrent and time-lagged relations. Journal of Applied Psychology, 75(6), 710-720. 
Meyer, J. P., Allen, N. J., \& Gellatly, I. R. (1990). Affective and continuance commitment to the organization: Evaluation of measures and analysis of concurrent and time-lagged relations. Journal of Applied Psychology, 75(6), 710-720.

Meyer, J. P., Allen, N. J., \& Smith, C. A. (1993). Commitment to organizations and occupations: Extension and test of a three-component conceptualization. Journal of applied psychology, 78(4), 538.

Mowday, R. T., Porter, L. W., \& Steers, R.M., (1982). Employee-organization linkages: the psychology of commitment, absenteeism and turnover. New York: Academic Press.

Murray A. H. (1938). Explorations in Personality. New York, NY: Oxford University press, 531-545.

Neuman, W. L. (2006). Workbook for Neumann Social research methods: qualitative and quantitative approaches. Allyn \& Bacon.

Neuman, W. L. (2013). Social Research Methods: Qualitative and Quantitatif Approaches (7th editio). PT Indeks.

Neuman, W. L. (2014). Social research methods: Qualitative and quantitative approaches: Pearson new international edition. Pearson Education Limited.

Neuman, W.L. (2011) Social Research Methods Qualitative and Quantitative Approaches. 7th Edition, Pearson, Boston.

Ozcelik \& Barsade, 2018. No Employee an Island: Workplace Loneliness and Job Performance.

Peter M. Blau, (1964), Justice in Social Exchange.

Schachter S. (1959). The Psychology of Affiliation. Stanford, CA: Stanford University Press.

Timothy J.Freeman, Kennon A. Lattal, (1922). The Exprerimental Analysis of Behaviour (Stimulus Control of Behavioral History)

Weiss, R. S. (1973). Loneliness: The experience of emotional and social isolation. The MIT Press. 